\title{
Oxidative Stress Induced by Polymyxin E Is Involved in Rapid Killing of Paenibacillus polymyxa
}

\author{
Zhiliang Yu, Yuyi Zhu, Wangrong Qin, Jianhua Yin, and Juanping Qiu \\ College of Biotechnology and Bioengineering, Zhejiang University of Technology, Hangzhou, China \\ Correspondence should be addressed to Zhiliang Yu; zlyu@zjut.edu.cn and Juanping Qiu; qiujping@zjut.edu.cn
}

Received 21 November 2016; Accepted 19 January 2017; Published 22 February 2017

Academic Editor: Swaran J. S. Flora

Copyright (C) 2017 Zhiliang Yu et al. This is an open access article distributed under the Creative Commons Attribution License, which permits unrestricted use, distribution, and reproduction in any medium, provided the original work is properly cited.

Historically, the colistin has been thought to kill bacteria through membrane lysis. Here, we present an alternative mechanism that colistin induces rapid Paenibacillus polymyxa death through reactive oxygen species production. This significantly augments our understanding of the mechanism of colistin action, which is critical knowledge toward the yield development of colistin in the future.

\section{Introduction}

Polymyxin E, also called colistin, is biosynthesized by Paenibacillus polymyxa [1]. As a nonribosomal cyclic lipopeptide antibiotic, it is recognized as one of the final options of antibiotic therapy for multidrug-resistance (MDR) bacteria resistant to almost all other currently used antibiotics [2]. Development of MDR pathogens against common antibiotics is increasing worldwide at an alarming rate. Although the concerns on colistin nephrotoxicity and neurotoxicity still remain, the use of colistin in many health care centers has been reevaluated by medical community [3]. Colistin bears several positively charged 2,4-diaminobutyric acids (Dab) which readily bind to the negatively charged lipid A on the cell membrane via electrostatic attraction. Upon initial binding, colistin displaces the divalent cations $\left(\mathrm{Ca}^{2+}\right.$ and $\left.\mathrm{Mg}^{2+}\right)$ on the membrane and inserts its hydrophobic segments into membrane, thus weakening the packing of adjacent lipid $A$ and causing membrane expansion [4,5]. As a result of destabilized area formation [6,7], colistin destroys the physical integrity of phospholipid bilayer on the membrane and causes membrane lysis [8]. It is generally believed that colistin only kills the Gram-negative bacteria by inducing membrane lysis $[9,10]$.

Recent report showed an alternative mechanism of colistin against Gram-negative bacteria [11]. Colistin stimulates the production of highly deleterious hydroxyl radicals $\left({ }^{\circ} \mathrm{OH}\right)$, leading to Gram-negative bacteria cell death. However, the mechanism underlying ${ }^{\circ} \mathrm{OH}$ formation is not very clear yet. One explanation is that the mechanism of ${ }^{\circ} \mathrm{OH}$ formation induced by bactericidal antibiotics is probably the end product of oxidative damage to cell involving generation of superoxide $\left(\mathrm{O}_{2}{ }^{-}\right)$, destabilization of Fe-sulfur (Fe-S) clusters, and stimulation of Fenton reaction [12]. Upon exposure to antibiotics, a modest surge in consumption of $\mathrm{NADH}$ generated from $\mathrm{NAD}^{+}$via tricarboxylic acid (TCA) cycle likely induces a burst in $\mathrm{O}_{2}{ }^{-}$generation via accelerated respiratory chain $[12,13]$. Furthermore, antibiotics induce cellular redox state alterations, and these toxic perturbations may contribute to the lethality of antibiotics $[14,15]$. Fe$S$ clusters are highly susceptible to oxidative attack from $\mathrm{O}_{2}{ }^{-}$, leading to the release of ferrous irons $\left(\mathrm{Fe}^{2+}\right)$. On the other side, $\mathrm{O}_{2}{ }^{-}$will be converted to $\mathrm{H}_{2} \mathrm{O}_{2}$ by superoxide dismutases (SOD) present in the cell. Subsequently, $\mathrm{H}_{2} \mathrm{O}_{2}$ will oxidize $\mathrm{Fe}^{2+}$ to ferric iron $\left(\mathrm{Fe}^{3+}\right)$, along with ${ }^{\circ} \mathrm{OH}$ formation, which is called Fenton reaction [16]. All these biologically oxidative species including $\mathrm{O}_{2}{ }^{-}, \mathrm{H}_{2} \mathrm{O}_{2}$, and ${ }^{\circ} \mathrm{OH}$ are called reactive oxygen species (ROS). When the concentration of ROS reaches uncontrollable level, it will result in oxidative damage to DNA, lipids and proteins, and eventually cause cell death $[17,18]$. In this process, oxidative damage of $\mathrm{Fe}-\mathrm{S}$ clusters is a key source of $\mathrm{Fe}^{2+}$ driving ${ }^{\circ} \mathrm{OH}$ formation and the elevated intracellular $\mathrm{Fe}^{2+}$ has been shown to mediate 
cellular damage not only directly but also via additional ${ }^{\circ} \mathrm{OH}$ formation [19]. The inactivation of intracellular Fe-S cluster will damage the $\mathrm{Fe}-\mathrm{S}$ dependent proteins, especially $\mathrm{Fe}-\mathrm{S}$ dependent dehydratases such as dihydroxy-acid dehydratase (DHAD). The damaged DHAD can be repaired by protein YggX (a member of SoxRS regulon) and di-iron protein YtfE in the presence of $\mathrm{Fe}^{3+}$ whose introduction is strongly triggered by ferric uptake regulator (Fur) [20].

Current understanding of the antibacterial mechanisms of colistin mainly focuses on Gram-negative bacteria. The knowledge on its bactericidal activity against the Grampositive bacteria is extremely little. Yet, few studies showed that colistin can also kill the Gram-positive bacteria [10], but the detailed mechanism is not clear [21, 22]. In this study, we demonstrated that colistin can induce the ROS accumulation in its producer P. polymyxa, a Gram-positive bacterium, probably playing a key role in rapid killing of Gram-positive bacterial cells. Since colistin is produced by $P$. polymyxa, its bactericidal activity against its producer would potentially repress its accumulation during fermentation. Therefore, our findings not only enrich our understanding of the bactericidal activity of colistin against Gram-positive bacteria but also help to improve its fermentation output in the future.

\section{Materials and Methods}

2.1. Strain and Culture Condition [10]. P. polymyxa used in this work was supplied by Zhejiang Qianjiang Biochemical Co., Ltd., China, and frozen at $-80^{\circ} \mathrm{C}$ in our lab. Unless otherwise stated, $P$. polymyxa was grown on solid medium including $10 \mathrm{~g} / \mathrm{L}$ of beef extract, $15 \mathrm{~g} / \mathrm{L}$ of peptone, $10 \mathrm{~g} / \mathrm{L}$ of glucose, $2 \mathrm{~g} / \mathrm{L}$ of yeast extract, $3 \mathrm{~g} / \mathrm{L}$ of $\mathrm{NaCl}$, and $18 \mathrm{~g} / \mathrm{L}$ of agar at $30^{\circ} \mathrm{C}$ for $2 \mathrm{~d}$. Then, a ring of $P$. polymyxa was inoculated to $50 \mathrm{~mL}$ of broth medium (solid medium without agar) in $250 \mathrm{~mL}$ flask for incubation at $30^{\circ} \mathrm{C}$ for $18 \mathrm{~h}$ with a shaking at $200 \mathrm{rpm}$.

2.2. Treatment of P. polymyxa by Colistin [10]. Upon broth incubation, the cells were collected by centrifugation at $5,000 \mathrm{~g}$ for $10 \mathrm{~min}$. After washing once with fresh broth medium, the cells were resuspended in fresh broth medium with appropriate volume to make a final cell concentration of about $10^{7}$ colony-forming units per milliliter $(\mathrm{CFU} / \mathrm{mL})$. Then, unless otherwise specified, colistin with a final concentration of $1.6 \times 10^{5} \mathrm{U} / \mathrm{mL}$ (supplied by Zhejiang Qianjiang Biochemical Co., Ltd., China) together with or without radical scavenging compound was added to cell solution and the mixture was incubated for various times at $30^{\circ} \mathrm{C}$ with a shaking at $200 \mathrm{rpm}$. One unit is equal to $0.0418 \mu \mathrm{g}$ of colistin.

2.3. Detection of Total Plate Count. After colistin treatment with or without radical scavenging compound, the mixture was centrifuged at $4,000 \mathrm{~g}$ for $5 \mathrm{~min}$. After washing twice with fresh broth medium, the cells were resuspended and appropriately diluted in fresh broth medium. Then, appropriate volume of cells was spread to solid medium for growth. After cultivation at $30^{\circ} \mathrm{C}$ for $2 \mathrm{~d}$, CFU was counted.
2.4. Measurement of Intracellular Levels of ROS. The intracellular levels of ROS were measured using a reactive oxygen species assay kit (Beyotime, Jiangsu, China) according to manufacturer's protocol. In general, $1 \mathrm{~mL}$ of bacterial cells $\left(10^{7} \mathrm{CFU} / \mathrm{mL}\right)$ with or without treatment of colistin was subjected to $30 \mu \mathrm{L}$ of $10 \mu \mathrm{M}$ 2,7-dichlorofluorescein diacetate (DCFH-DA). After treatment at $37^{\circ} \mathrm{C}$ for $20 \mathrm{~min}$, the cells were collected with centrifugation at $4,000 \mathrm{~g}$ for $5 \mathrm{~min}$ and washed twice with fresh broth medium. After resuspension in $1 \mathrm{~mL}$ of fresh broth medium, $200 \mu \mathrm{L}$ of the cells were analyzed by a multimode reader (SpectraMax M2, USA) with excitation and emission of 488 and $525 \mathrm{~nm}$, respectively.

2.5. Determination of Lipid Peroxidation. Lipid peroxidation was evaluated based on the production of malondialdehyde (MDA) which was quantified using thiobarbituric acid assay [24]. In brief, $1 \mathrm{~mL}$ of bacterial cells $\left(10^{7} \mathrm{CFU} / \mathrm{mL}\right)$ with or without treatment of colistin was collected with centrifugation at $4,000 \mathrm{~g}$ for $5 \mathrm{~min}$ and washed twice with fresh broth medium. Then, the cells were resuspended in $100 \mu \mathrm{L}$ of breaking solution containing 5\% SDS and $250 \mathrm{mM}$ EDTA for incubation at $37^{\circ} \mathrm{C}$ for $30 \mathrm{~min}$. Next, according to manufacturer's protocol, the MDA in mixture was detected using an MDA assay kit (Beyotime, Jiangsu, China) and analyzed by a multimode reader (SpectraMax M2, USA) at a wavelength of $532 \mathrm{~nm}$.

2.6. Genomic DNA Extraction and Analysis. One milliliter of bacterial cells $\left(10^{7} \mathrm{CFU} / \mathrm{mL}\right)$ was treated with or without colistin for various times as needed. Then, the cells were collected with centrifugation at $4,000 \mathrm{~g}$ for $5 \mathrm{~min}$ and washed twice with fresh broth medium. Next, the cells were subjected to lysis buffer containing $125 \mu \mathrm{L}$ of $500 \mathrm{mM}$ EDTA with $\mathrm{pH}$ $8.0,20 \mu \mathrm{L}$ of $10 \mathrm{mg} / \mathrm{mL}$ lysozyme and $1 \mu \mathrm{L}$ of $10 \mathrm{mg} / \mathrm{mL}$ RNA enzyme for incubation at $37^{\circ} \mathrm{C}$ for $30 \mathrm{~min}$. Subsequently, $70 \mu \mathrm{L}$ of $10 \%$ SDS together with $5 \mu \mathrm{L}$ of $10 \mathrm{mg} / \mathrm{mL}$ protease $\mathrm{K}$ were added to lysis solution for further incubation at $55^{\circ} \mathrm{C}$ for $30 \mathrm{~min}$. Then, the sample was completely mixed with $70 \mu \mathrm{L}$ of $\mathrm{NaCl}$. After ice-bath for $30 \mathrm{~min}$, the mixture was centrifuged at $12,000 \mathrm{~g}$ for $30 \mathrm{~min}$ at $4^{\circ} \mathrm{C}$. The supernatant was mixed with an equal volume of Tris-phenol. After centrifugation at $12,000 \mathrm{~g}$ for $10 \mathrm{~min}$ at $4^{\circ} \mathrm{C}$, the supernatant was mixed with two volume of ice-cold absolute ethanol for precipitation at $-20^{\circ} \mathrm{C}$ for $20 \mathrm{~min}$. After centrifugation at $12,000 \mathrm{~g}$ for $10 \mathrm{~min}$ at $4^{\circ} \mathrm{C}$ followed by washing with $500 \mu \mathrm{L}$ of $75 \%$ ice-cold ethanol, the DNA pellets were air-dried and dissolved in around $50 \mu \mathrm{L}$ of $\mathrm{ddH}_{2} \mathrm{O}$. After concentration balance, the DNA samples were run on a $1 \%$ agarose gel and visualized under UV light.

2.7. Cloning of P. polymyxa Genes. The primers listed in Table 1 were designed using Primer Premier 5.0 software based on the reference gene sequences from P. polymyxa E681 (GenBank accession number CP000154) and P. polymyxa SC2 (GenBank accession number CP002213) and synthesized by Invitrogen (Carlsbad, California, USA). PCR was performed in a final volume of $50 \mu \mathrm{L}$ containing $2 \mathrm{ng} P$. polymyxa genomic DNA, $100 \mathrm{nM}$ each of primers, $62.5 \mu \mathrm{M}$ each of dNTPs, $50 \mathrm{mM} \mathrm{KCl,} 10 \mathrm{mM}$ Tris- $\mathrm{HCl}, 1.5 \mathrm{mM} \mathrm{MgCl}$, and $1 \mathrm{U}$ 
TABLE 1: Primers used for gene amplification in the PCR.

\begin{tabular}{|c|c|c|}
\hline Gene $^{a}$ & Forward sequence $^{\mathrm{b}}\left(5^{\prime}-3^{\prime}\right)$ & Reverse sequence $\left(5^{\prime}-3^{\prime}\right)$ \\
\hline $\operatorname{sod} A$ & GGCATTTCAATTACCAGAAC & GCAGCCGCGTAACGTTTGTT \\
\hline $\operatorname{sod} B$ & ATGCTGAGTACTTATGGGTCTTTCC & TTAGAAGGGTTGCCATCTCAGC \\
\hline$i l v D$ & GCGGTCCTATGAAAGCTGGT & CGTTACTTGCGTTCGTCACC \\
\hline Fur & CCGTGGAAGTCCAAACGATG & GCAATCCCAGGGCTACAAAC \\
\hline Dps & AACCGTCAAGTCGCTAACCT & CCCAAATAAGAGCGCAGCATC \\
\hline $16 \mathrm{~S}$ rRNA & AGAGTTTGATCCTGGCTCAG & ACGGCTACCTTGTTACGACTT \\
\hline
\end{tabular}

${ }^{a}$ The $\operatorname{sod} A$, sodB, ilvD, Fur, and Dps encode Mn-superoxide dismutase (Mn-SOD), Fe-superoxide dismutase (Fe-SOD), dihydroxy-acid dehydratase (DHAD), Fur-like protein, and DNA-binding proteins (Dps), respectively.

${ }^{\mathrm{b}}$ The primers for different genes were designed based on the reference gene sequences of $P$. polymyxa E681 (GenBank accession number CP000154) and $P$. polymyxa SC2 (GenBank accession number CP002213), and the primers of 27F and 1492R were used for 16S rRNA gene.

TABLE 2: Primers used for quantitative real-time PCR.

\begin{tabular}{llr}
\hline Gene & Forward sequence $\left(5^{\prime}-3^{\prime}\right)$ & Reverse sequence $\left(5^{\prime}-3^{\prime}\right)$ \\
\hline $\operatorname{sod} A$ & CCAATCTGGACAGCGTTCCT & CGCCGTTAGGAGCGATAACT \\
$\operatorname{sodB}$ & GGGAGTCTATTCCGCTGCTG & TGACGACATGCCACCAATCT \\
$i l v D$ & CAATGAAGTCGCGAACCGTG & CATTCAGCACTGCGCTTACG \\
D $p s$ & CTCCTCTAACGGTCCAAGCC & TATGATTTGCGCGGCGATAC \\
$16 \mathrm{~S}$ rRNA & AAGGTTCTCCTTCCGCAACA & CCTCAATCAGGGTTTGCACC \\
\hline
\end{tabular}

Taq polymerase (Amersham Biosciences, Piscataway, USA). PCR amplification consisted of denaturation at $95^{\circ} \mathrm{C}$ for $5 \mathrm{~min}$, followed by 35 cycles of $30 \mathrm{~s}$ at $95^{\circ} \mathrm{C}, 30 \mathrm{~s}$ at $55^{\circ} \mathrm{C}, 2 \mathrm{~min}$ at $72^{\circ} \mathrm{C}$, and a final extension step at $72^{\circ} \mathrm{C}$ for $10 \mathrm{~min}$. At the end of the reaction, the reaction mixture was cooled to $4^{\circ} \mathrm{C}$ to await further manipulations. The PCR products were resolved on $1.0 \%$ agarose gel for electrophoresis, and the product size was checked on the gel stained with ethidium bromide under UV. After size confirmation, the target DNA in gel was extracted using MiniBEST Agarose Gel DNA Extraction Kit (TaKaRa, Dalian, China) and cloned into pMD19-T simple vector (TaKaRa, Dalian, China). Finally, each gene sequence was determined after sequencing (Sangon, Shanghai, China).

\subsection{Analysis of Gene Expression Using Quantitative Real-Time} PCR ( $q R T-P C R)$. To measure the gene expression, qRT-PCR was used to amplify cDNA products reversely transcribed from mRNA $[25,26]$. In brief, the bacterial cell was harvested through centrifugation at $5,000 \mathrm{~g}$ for $5 \mathrm{~min}$ and the total RNA was extracted using an RNAiso Plus kit (Sangon, Shanghai, China). RNA integrity was determined based on the $\mathrm{OD}_{260 \mathrm{~nm}} / \mathrm{OD}_{280 \mathrm{~nm}}$ ratio (>1.95), and $500 \mathrm{ng}$ of DNAfree RNA with high-quality was reversely transcribed to cDNA in a $10 \mu \mathrm{L}$ volume using PrimeScript ${ }^{\mathrm{TM}}$ RT Master Mix (Perfect Real-Time) kit. After appropriate dilution, the cDNAs were used to amplify the target gene fragments from $100 \mathrm{bp}$ to $120 \mathrm{bp}$ with primer sets (Table 2) by using the SYBR green Premix Ex Taq $^{\mathrm{TM}}$ (Tli RNaseH Plus) kit. PCR was run on CFX Connect Real-Time System (Bio-Rad, Hercules, CA) based on an amplification protocol consisting of an initial denaturation at $95^{\circ} \mathrm{C}$ for $10 \mathrm{~min}$, followed by 40 cycles of denaturation at $95^{\circ} \mathrm{C}$ for $15 \mathrm{~s}$ and annealing/elongation at $60^{\circ} \mathrm{C}$ for $30 \mathrm{~s}$. Immediately after the final PCR cycle, a melting-curve analysis was made to determine the reaction specificity based on the observed melting temperature from product. Unless otherwise specified, all the kits above were purchased from TaKaRa Bio. Inc. (Dalian, China).

The cycle threshold $\left(C_{T}\right)$ for each PCR was determined using STATVIEW software which automatically set the threshold signal at the log phase of amplification curve. Several dilutions of each cDNA sample were assayed for gene of interest in order to obtain a linear regression between the $C_{T}$ values (ranging from 20 to 35 cycles) and the log of cDNA. The amplification efficiency of gene was retrieved from the slope of that linear regression according to the formula $E=10^{(-1 / \text { slope })}$. The 116 bp of housekeeping $16 \mathrm{~S}$ rRNA gene fragment was amplified and treated as the internal control to verify that there were equal amounts of target cDNA in all samples. The relative expression of the target gene compared to that of the reference $16 \mathrm{~S}$ rRNA gene was calculated by comparative $C_{T}$ method [27].

2.9. Detection of $\mathrm{Fe}^{3+}$ Based on Ferric-Xylenol Orange Formation. Xylenol orange $(\mathrm{XO})$ can combine with $\mathrm{Fe}^{3+}$ to form purplish $\mathrm{Fe}^{\mathrm{III}} \mathrm{XO}$. Unless otherwise stated, $\mathrm{Fe}^{\mathrm{III}} \mathrm{XO}$ agar assay was used for detection of the concentration of $\mathrm{Fe}^{3+}$ [28] as follows: (1) prepare $20 \mathrm{~mL}$ of working solution containing $800 \mu \mathrm{L}$ of $1 \mathrm{M} \mathrm{H}_{2} \mathrm{SO}_{4}, 2 \mathrm{~mL}$ of $1 \mathrm{M} \mathrm{D}$-Sorbitol, $3 \mathrm{~mL}$ of $1 \mathrm{mM}$ $\mathrm{XO}$, and $14.2 \mathrm{~mL}$ of $\mathrm{ddH}_{2} \mathrm{O}$; (2) make $50 \mathrm{~mL}$ of $2 \%$ agar solution and dissolve the mixture completely at $100^{\circ} \mathrm{C}$ for $5 \mathrm{~min}$; (3) mix working solution with agar solution and pour into glass Petri dish to make agar plate; (4) make circular wells on agar plate with a hole puncher whose diameter is $6 \mathrm{~mm}$; (5) add $50 \mu \mathrm{L}$ of detection solution to each well and wait for 


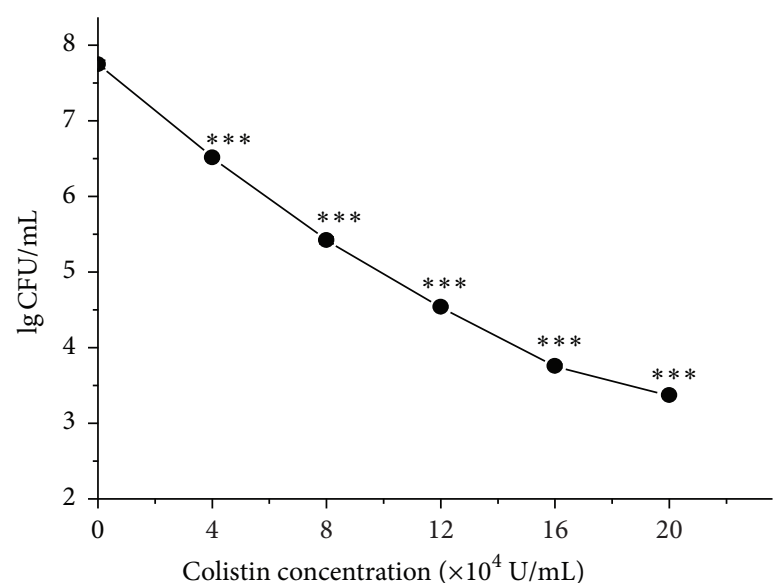

(a)

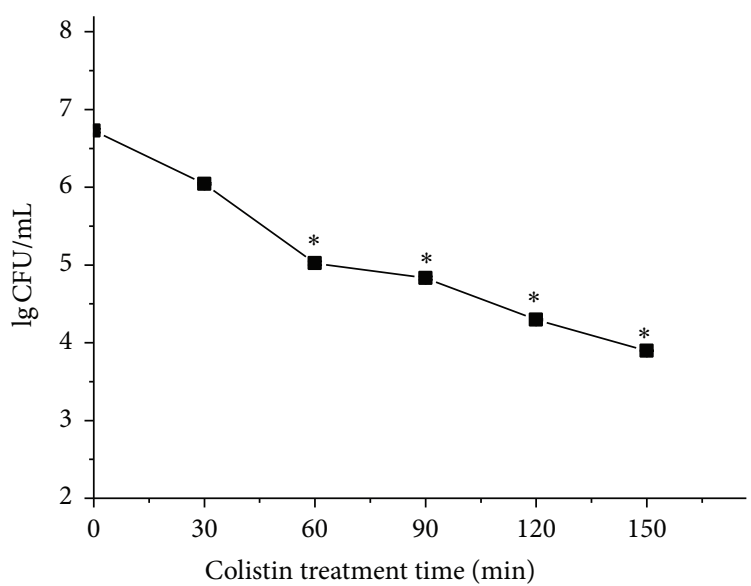

(b)

Figure 1: Colistin-induced rapid killing of $P$. polymyxa. (a) Colistin with various concentrations for $2 \mathrm{~h}$; (b) colistin at $8 \times 10^{4} \mathrm{U} / \mathrm{mL}$ for various times. After treatment, cell solution with appropriate dilution was plated for cultivation and the CFU was counted.

$60 \mathrm{~min}$ at room temperature for color change; (6) visualize the $\mathrm{Fe}^{\mathrm{III}} \mathrm{XO}$ formation and measure the size of purplish red halo. A series of standard $\mathrm{Fe}^{3+}$ solutions with different concentrations were used to extract the correlation between $\mathrm{Fe}^{3+}$ concentration and diameter of the formed purplish red halo.

2.10. Data Analysis. All data were presented as mean \pm standard error and tested for statistical significance based on analysis of variance (ANOVA) followed by Dunnett's post hoc test using StatView 5.0 program. When the probability $(p)$ was less than $0.05,0.01$, and 0.001 , the values were considered significantly $(*)$, very significantly $(* *)$, and extremely significantly $(* * *)$ different, respectively.

\section{Results}

3.1. Rapid Killing of P. polymyxa Induced by Colistin. Bactericidal activity of colistin against $P$. polymyxa was tested based on total plate count assay. Results in Figure 1(a) show that colistin with concentration from $4 \times 10^{4} \mathrm{U} / \mathrm{mL}$ to 2 $\times 10^{5} \mathrm{U} / \mathrm{mL}$ all causes extremely significant decrease of the cell survival. Besides, its bactericidal activity is positively correlated with its concentration. As the colistin concentration increases, the cell survival correspondingly decreases. In addition, data in Figure 1(b) indicate that the bactericidal activity of colistin against $P$. polymyxa is time-dependent. The longer the treatment, the stronger the bactericidal activity. These findings, together with others' studies [21, 22], expand the bactericidal activity of colistin to Gram-positive bacteria.

\subsection{ROS Accumulation and Oxidative Stress-Induced Damage} in Colistin-Exposed P. polymyxa Cells. Using the dye DCFHDA (autofluorescence unit is 60.678) which could be oxidized to DCF-DA by ROS [29], we specifically detected the ROS accumulation in bacterial cells treated with colistin. Compared to the control, the fluorescence signal significantly increases in the presence of colistin (Figure 2(a)), suggesting that colistin could induce the ROS accumulation in $P$. polymyxa. It has been revealed that the oxidative stress can drive the oxidization of lipid in cell membrane and degradation of DNA [30]. Our results in Figure 2(b) also show that the cells subjected to $8 \times 10^{4} \mathrm{U} / \mathrm{mL}$ colistin yield around $7 \mu \mathrm{M}$ of MDA, an oxidized product of polyunsaturated fatty acid, extremely and significantly higher than $1 \mu \mathrm{M}$ of $\mathrm{MDA}$ in the cells without colistin. Additionally, analysis of genomic DNA in agarose gel (Figure 2(c)) indicates that colistin induces the genomic DNA degradation in P. polymyxa accompanied by an increase in DNA smear with the increase in colistin concentration. As Fe-S cluster protein, DHAD is extremely sensitive to oxidative stress [20]. Figure 2(d) shows that the relative expression of $i l v D$ (encoding DHAD) is downregulated by colistin. Taken together, our results suggest that colistin can induce ROS accumulation in P. polymyxa, subsequently killing Gram-positive bacteria cells by triggering diverse damage.

3.3. Delay of Colistin-Induced Killing of $P$. polymyxa by Scavenging ROS. Considering the observation that colistin can induce ROS formation for killing of P. polymyxa, we sought to rescue colistin-treated cells by scavenging ROS. Accordingly, thiourea was first used as a potent scavenger to particularly quench ${ }^{\circ} \mathrm{OH}$, a type of ROS [31]. Figure 3(a) shows that colistin alone causes a pronounced decrease of $\mathrm{LgCFU} / \mathrm{mL}$ from around 7.4 to 5.4 within $2 \mathrm{~h}$, while extra addition of thiourea increases the $\mathrm{LgCFU} / \mathrm{mL}$ of $P$. polymyxa to 7.2 at $2 \mathrm{~h}$, close to the level without colistin. As expected, the treatment with thiourea alone has no obvious effect on $\mathrm{LgCFU} / \mathrm{mL}$ of $P$. polymyxa. These results indicate that thiourea is able to extremely and significantly relieve the colistin-mediated mortality to P. polymyxa. We further examined both glutathione (Figure 3(b)) and cysteine (Figure 3(c)), another two types of ROS sequesters, to rescue colistin-treated P. polymyxa. It was found that these two ROS sequesters yield overall similar results as thiourea. Notably, application of either glutathione or cysteine can increase the 


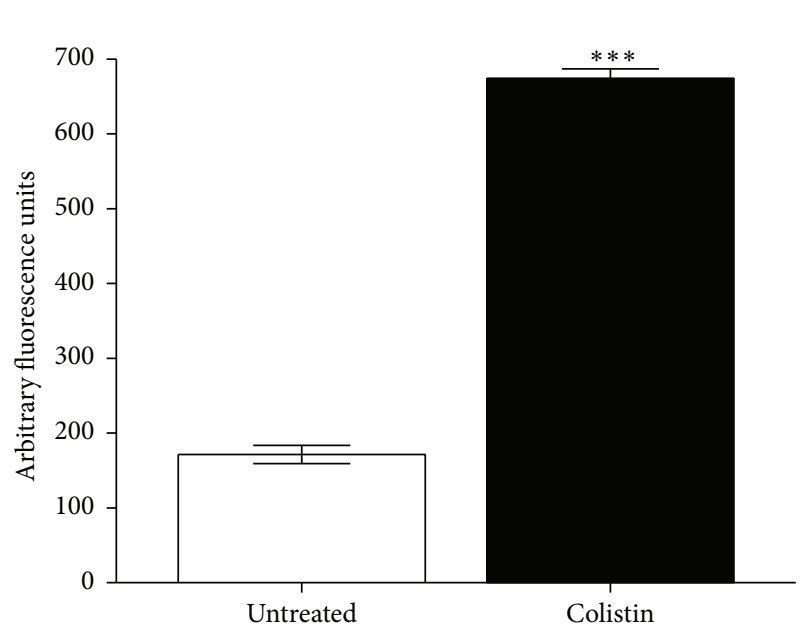

(a)

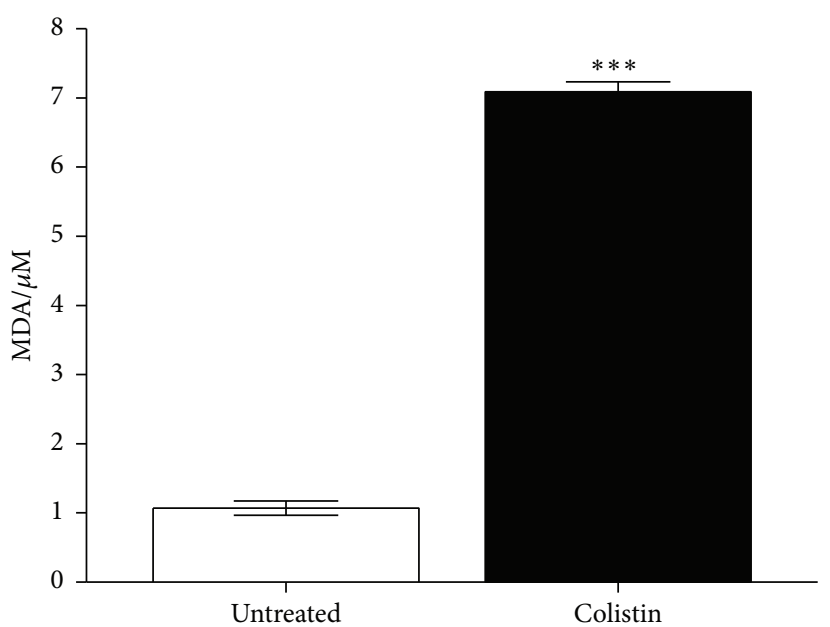

(b)

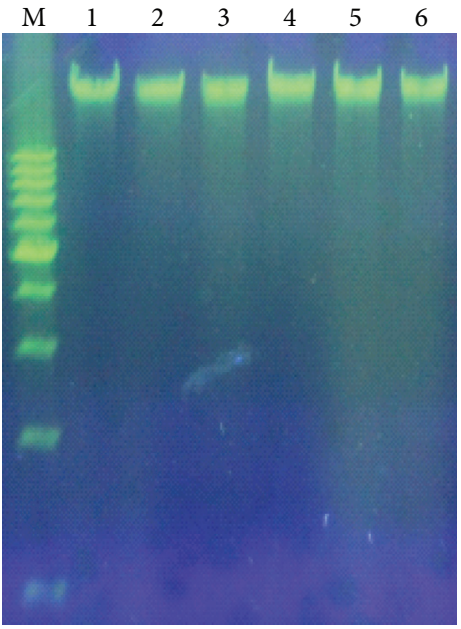

(c)

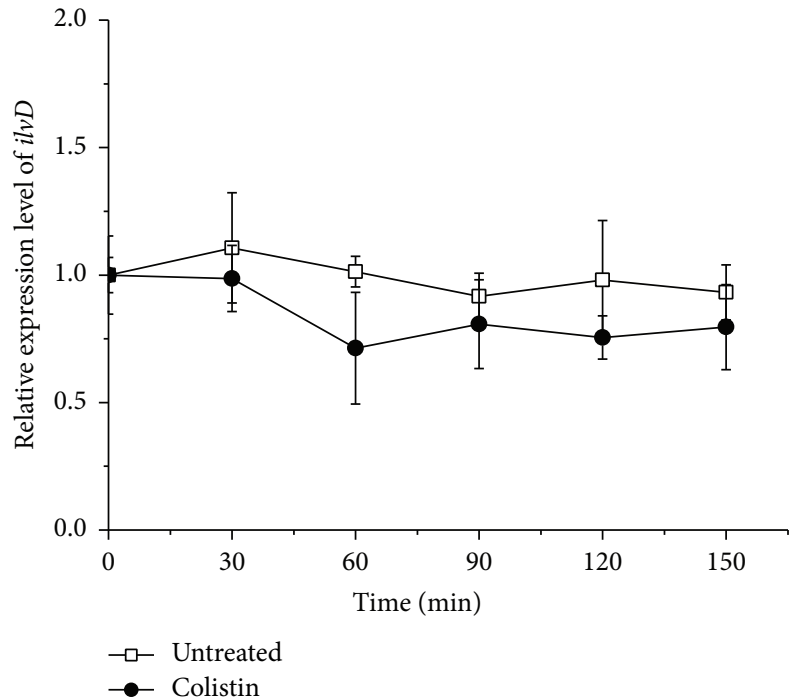

(d)

FIgURE 2: ROS accumulation in P. polymyxa and oxidative stress-induced damage to cell. (a) Fluorescence signal of DCF-DA converted from DCFH-DA due to oxidation, (b) lipid peroxidation production of MDA, (c) visualization of genomic DNA fragmentation, and (d) Relative expression level of $i l v D$ encoding for DHAD. For panels (a), (b), and (d), cells were treated with or without $1.6 \times 10^{5} \mathrm{U} / \mathrm{mL}$ colistin for $2 \mathrm{~h}$. The data are representative of three independent experiments. Points represent the means and bars represent the standard deviation of triplicate samples. For panel (c), lanes 1 to 6 refer to genomic DNA from P. polymyxa treated with $0,4 \times 10^{4} \mathrm{U} / \mathrm{mL}, 8 \times 10^{4} \mathrm{U} / \mathrm{mL}, 1.2 \times 10^{5} \mathrm{U} / \mathrm{mL}, 1.6 \times$ $10^{5} \mathrm{U} / \mathrm{mL}$, and $2.0 \times 10^{5} \mathrm{U} / \mathrm{mL}$ of colistin, respectively; $\mathrm{M}$ represents molecular mass marker.

survival close to the level without colistin at $1 \mathrm{~h}$. All these findings demonstrate that colistin stimulates the production of highly deleterious ROS in Gram-positive bacteria, which ultimately contributes to cell death. ROS sequesters can remarkably protect cells from the colistin-mediated killing.

3.4. Protective Response of P. polymyxa to Colistin-Induced Oxidative Stress. Typically, SOD plays a key role for cells to survive under oxidative stress [32,33]. Genome analysis reveals that $P$. polymyxa appears to have $\mathrm{Mn}-\mathrm{SOD}$ and $\mathrm{Fe}-$ SOD, encoded by $\operatorname{sod} A$ and $\operatorname{sod} B$, respectively. Mn-SOD synthesis is stimulated by $\mathrm{O}_{2}{ }^{-}$[34]. Fe-SOD is important for protecting cytoplasmic enzyme such as DHAD from oxidative damage [35]. Our results in Figure 4 display the changes in the relative expression level of $\operatorname{sod} A$ and $\operatorname{sodB}$ in $P$. polymyxa. The sodA expression is significantly stimulated by the addition of colistin and keeps increasing with the treatment time. Besides, it gives a near 3.5-fold increase relative to the treatment without colistin at $150 \mathrm{~min}$. In contrast, the $\operatorname{sodB}$ expression is also overall increased but fluctuated following addition of colistin, which is highly correlated with the change in the ilvD expression (Figure 2(d)). Most probably, the inactivation of DHAD in transcriptional level by colistin-induced oxidative stress needs transient activation of Fe-SOD for protection, a consistence with the report [35].

In addition to SOD, iron, and iron-associated proteins are also very important for cells to response with oxidative stress. $\mathrm{Fe}^{2+}$ is involved in extremely deleterious ${ }^{\circ} \mathrm{OH}$ formation via 


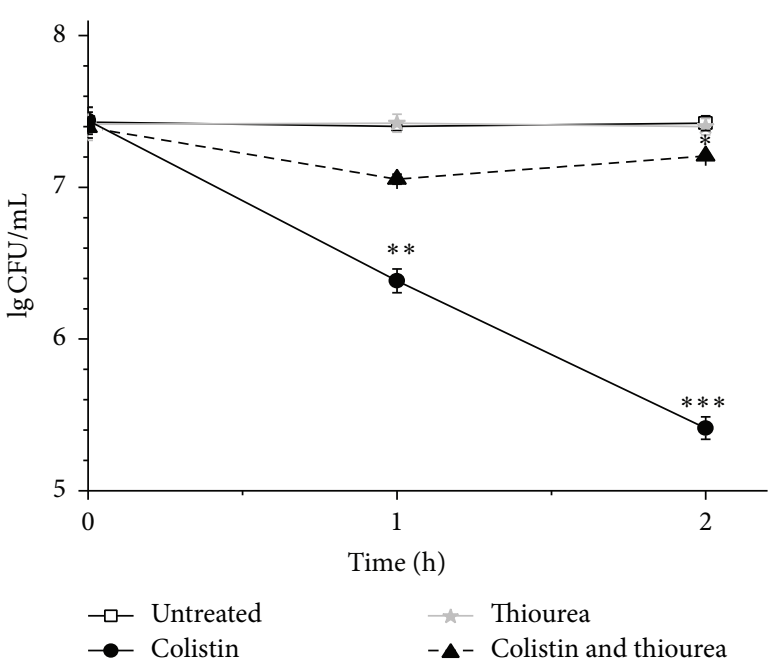

(a)

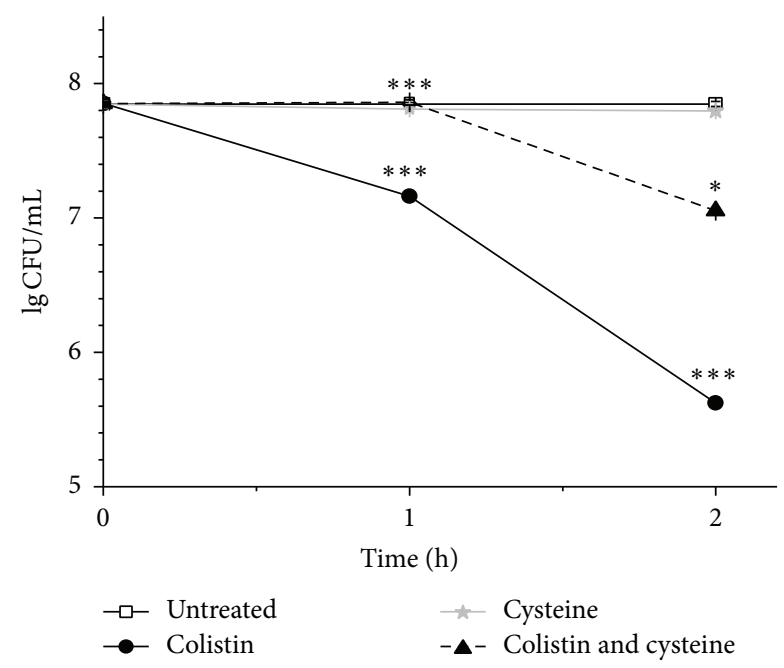

(b)

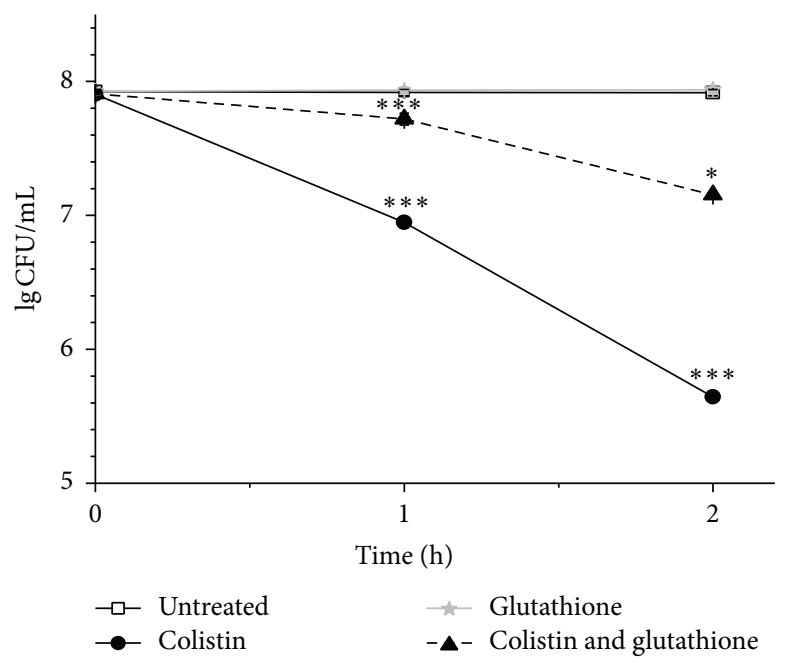

(c)

Figure 3: Delay of colistin-induced killing of $P$. polymyxa by scavenging ROS with $100 \mathrm{mM}$ thiourea (a), $100 \mathrm{mM}$ cysteine (b), or $100 \mathrm{mM}$ glutathione (c).

the Fenton reaction. Conversely, $\mathrm{Fe}^{3+}$ can be utilized to repair the damaged $\mathrm{Fe}-\mathrm{S}$ cluster proteins. Therefore, iron acquisition and metabolism are strictly regulated for cells to survive in oxidative stress. There is increasing evidence to reveal the coordination between regulation of iron homeostasis and defense of oxidative stress [36]. We prepared fresh broth media with different concentrations of $\mathrm{Fe}^{3+}$ for treatment of cells with colistin and subsequently using $\mathrm{Fe}^{\mathrm{III}} \mathrm{XO}$-formation agar assay [28] to determine the iron distribution both in supernatant solutions and inside cells. Figure 5(a) shows that the diameters of the purplish red hole formed by the supernatant collected from the solution in the absence of colistin (untreated), which expectedly keep increasing with higher $\mathrm{Fe}^{3+}$ concentration from 0 to $1 \mathrm{~g} / \mathrm{L}$ and saturated at $\mathrm{Fe}^{3+}>1 \mathrm{~g} / \mathrm{L}$, indicating the diameter of purplish red hole is positively sensitive to $\mathrm{Fe}^{3+}$ at detectable concentration for assay. Interestingly, treatment with colistin alone causes the diameter of purplish red hole derived from $\mathrm{Fe}^{3+}$ ranging from 0.05 to $1 \mathrm{~g} / \mathrm{L}$ significantly smaller relative to the untreated one, suggesting that colistin causes the disappear of partial $\mathrm{Fe}^{3+}$ from solution (Figure 5(a)). Presumably, due to the saturation caused by $\mathrm{Fe}^{3+}$ from 1 to $2 \mathrm{~g} / \mathrm{L}$, there is no clear discrepancy in diameter of purplish red hole between colistin absent and present. There are two possible reasons for disappear of $\mathrm{Fe}^{3+}$ under colistin exposure: (1) it has been turned to $\mathrm{Fe}^{2+} ;(2)$ it has been absorbed into cells. To test the first possibility, we additionally used $\mathrm{H}_{2} \mathrm{O}_{2}$ to oxidize the possibly formed $\mathrm{Fe}^{2+}$ in colistin-treated supernatant before detection and then measured $\mathrm{Fe}^{3+}$. The data in Figure 5(b) show that $\mathrm{H}_{2} \mathrm{O}_{2}$ treatment gives almost the similar results as the $\mathrm{H}_{2} \mathrm{O}_{2}$ untreated (Figure 5(a)) and does not obviously increase the diameter of purplish red hole formed from the colistin-subjected supernatant, thus demonstrating that the disappeared $\mathrm{Fe}^{3+}$ has been mostly assimilated into cells. 


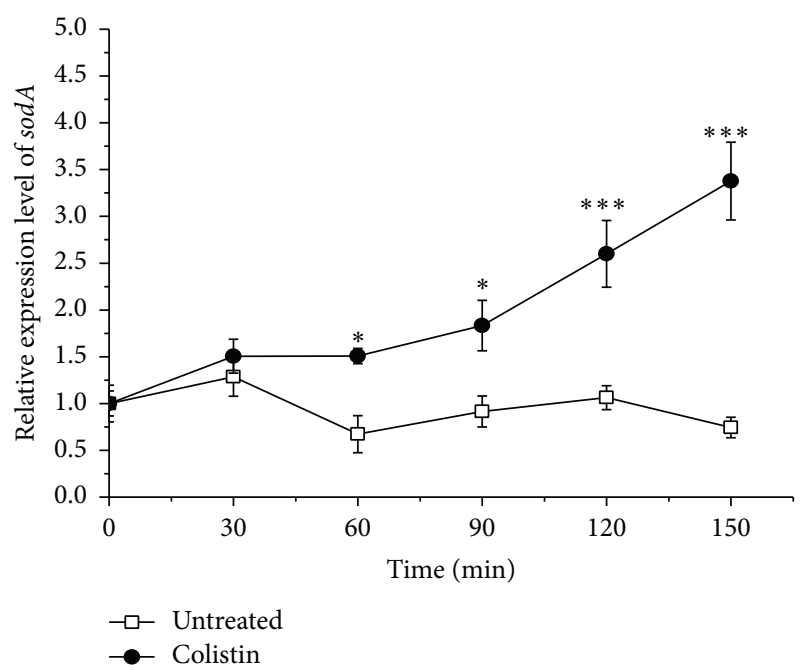

(a)

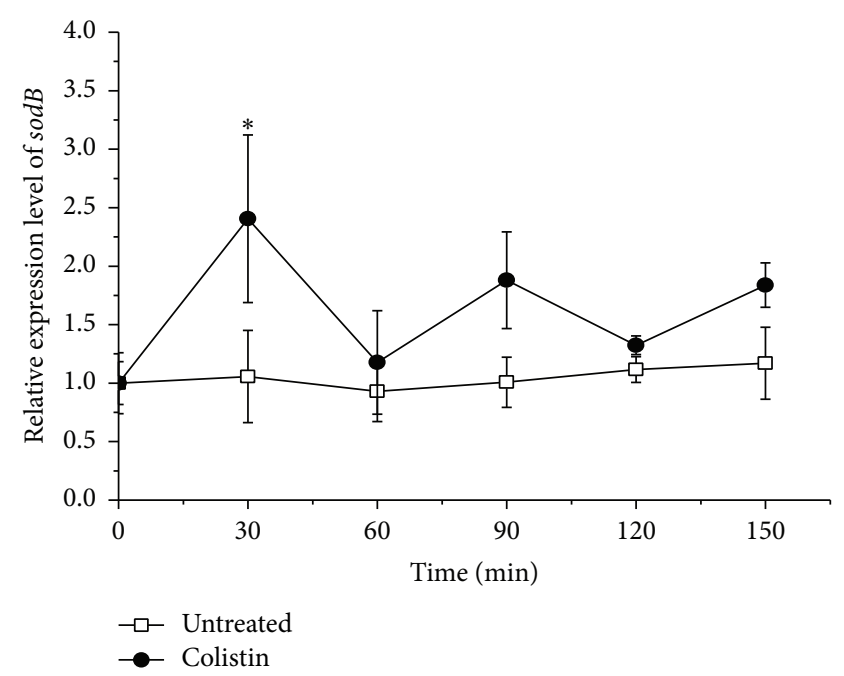

(b)

FIGURE 4: Effect of colistin on relative expression level of $\operatorname{sodA}(\mathrm{a})$ and $\operatorname{sodB}(\mathrm{b})$ encoding for Mn-SOD and Fe-SOD, respectively, in $P$. polymyxa.

Exceptionally, $\mathrm{H}_{2} \mathrm{O}_{2}$ treatment yields the marginally elevated diameter of purplish red hole relative to $\mathrm{H}_{2} \mathrm{O}_{2}$ absent at $\mathrm{Fe}^{3+}$ from 0.6 to $0.8 \mathrm{~g} / \mathrm{L}$, suggesting that very small portion of $\mathrm{Fe}^{2+}$ has been either formed from $\mathrm{Fe}^{3+}$ or released from cells when exposed to colistin. We next collected the cells for ultrasonication and then detected the released intracellular $\mathrm{Fe}^{3+}$ concentration in supernatant solution after centrifugation. As shown in Figure 5(c), there is no detectable and almost constant intracellular $\mathrm{Fe}^{3+}$ from colistin-absent cells when exposed to $\mathrm{Fe}^{3+}$ from 0 to $0.4 \mathrm{~g} / \mathrm{L}$ and 0.4 to $2 \mathrm{~g} / \mathrm{L}$, respectively, suggesting that treatment of $\mathrm{Fe}^{3+}$ only with high enough concentration causes the uptake of detectable $\mathrm{Fe}^{3+}$ into cells. Surprisingly, there is constantly no detectable intracellular $\mathrm{Fe}^{3+}$ from colistin-treated cells when exposed to $\mathrm{Fe}^{3+}$ from 0 to $2 \mathrm{~g} / \mathrm{L}$. The missing of the assimilated $\mathrm{Fe}^{3+}$ in colistintreated cells probably contributes to two reasons: (1) colistin is able to induce the conversion of intracellular $\mathrm{Fe}^{3+}$ to $\mathrm{Fe}^{2+}$; (2) colistin could result in the conjugation of intracellular $\mathrm{Fe}^{3+}$ with $\mathrm{Fe}^{3+}$-binding proteins. Next, we additionally used $\mathrm{H}_{2} \mathrm{O}_{2}$ to oxidize the possibly formed $\mathrm{Fe}^{2+}$ released from colistin-treated cells and detected the total $\mathrm{Fe}^{3+}$ concentration. Figure 5(d) shows that $\mathrm{H}_{2} \mathrm{O}_{2}$ treatment to colistin-free sample gives almost the same diameter of purplish red hole as the $\mathrm{H}_{2} \mathrm{O}_{2}$ untreatment (Figure 5(c)), thus suggesting that there is no obviously detectable $\mathrm{Fe}^{2+}$ in colistin-free cells. In contrast, $\mathrm{H}_{2} \mathrm{O}_{2}$ treatment to colistin-present sample with $\mathrm{Fe}^{3+}$ from 1.0 to $2 \mathrm{~g} / \mathrm{L}$ does additionally yield the detectable diameter of purplish red hole relative to the $\mathrm{H}_{2} \mathrm{O}_{2}$-untreated one, thus demonstrating colistin treatment is able to induce oxidative stress and correspondingly stimulate the conversion of absorbed $\mathrm{Fe}^{3+}$ to $\mathrm{Fe}^{2+}$ inside cells. On the other hand, additional $\mathrm{H}_{2} \mathrm{O}_{2}$ treatment to colistin-present sample with $\mathrm{Fe}^{3+}$ less than $1.0 \mathrm{~g} / \mathrm{L}$ is unable to create the detectable purplish red hole. Besides, when colistin-treated cells are subjected to $\mathrm{Fe}^{3+}$ ranging from 1.0 to $2 \mathrm{~g} / \mathrm{L}$, the diameter of purplish red hole from $\mathrm{Fe}^{3+}$ oxidized from intracellular $\mathrm{Fe}^{2+}$ by $\mathrm{H}_{2} \mathrm{O}_{2}$ is smaller than the one from colistin-absent sample. All these findings support the fact that colistin can induce cells to couple iron with binding proteins for iron sequestering or Fe-S clusters repair, which is important for cell survival.

Fur-like protein (Fur), encoded by fur, has been reported to regulate $\mathrm{Fe}^{3+}$ assimilation with defense against oxidative defense [36]. Besides, DNA-binding protein from starved cells (Dps), encoded by $d p s$, has been found to prevent DNA cleavage from oxidative stress by sequestering $\mathrm{Fe}^{2+}$ [37]. We next sought to investigate the differentiated expression of fur and $d p s$ in $P$. polymyxa cells when exposed to colistin. The data in Figure 6 show that the relative expressions of both fur and $d p s$ from colistin-treated cells appear to extraordinarily increase relative to the colistin-untreated ones. In addition, the extent of elevated expression of both genes is positively associated with the treatment time. Most probably, to survive, the colistin-exposed cells increase the expression of fur and $d p s$ for iron uptake and sequestering, thus suggesting that $\mathrm{Fe}^{3+}$ assimilation plays a critical role for cells to defense with colistin-induced oxidative stress. Therefore, we next sought to directly block the harmful effects of colistin-induced oxidative stress by adding $\mathrm{Fe}^{3+}$ to drug-treated cultures. It was found that cultures treated with colistin and $\mathrm{Fe}^{3+}$ show a significant delay in cell death and particularly a near 1.8 $\log$ increase in survival at $0.6 \mathrm{~g} / \mathrm{L} \mathrm{Fe}^{3+}$ relative to colistin treatment alone (Figure 7), demonstrating that $\mathrm{Fe}^{3+}$ is able to mitigate bacterial cell death following colistin treatment. On the other hand, there is a slight drop in $\mathrm{LgCFU} / \mathrm{mL}$ at $1.0 \mathrm{~g} / \mathrm{L} \mathrm{Fe}^{3+}$, which is most probably due to slight toxic of $\mathrm{Fe}^{3+}$ at high concentration to cells as shown in colistin-absent treatment. 


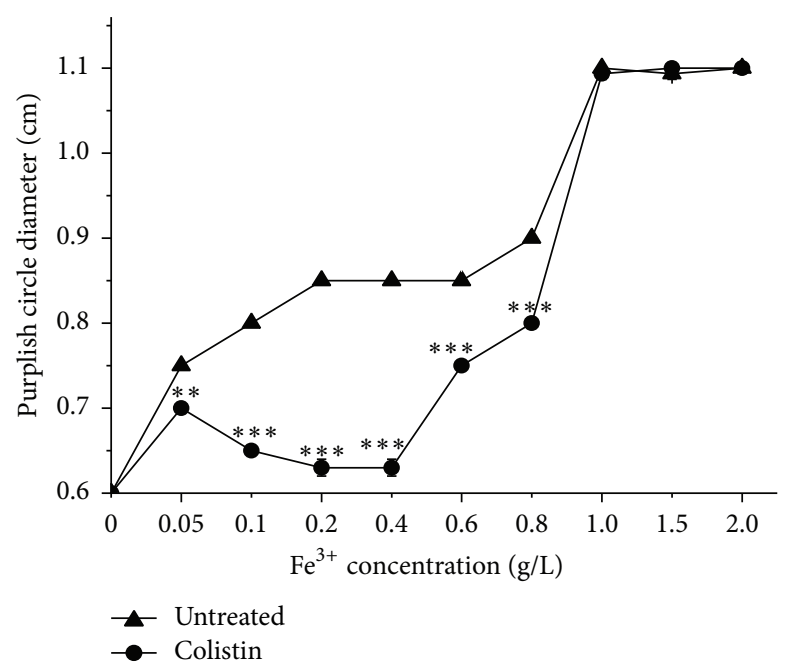

(a)

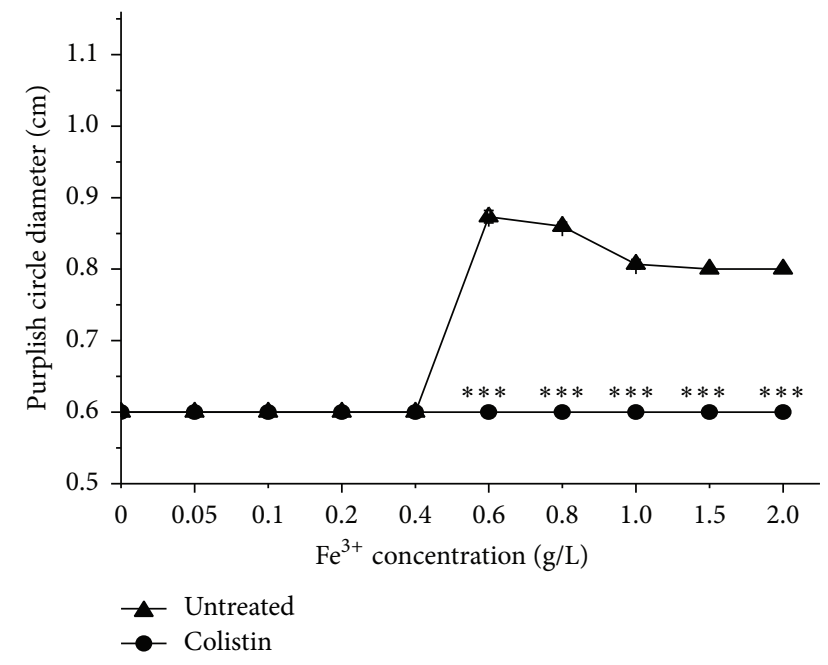

(c)

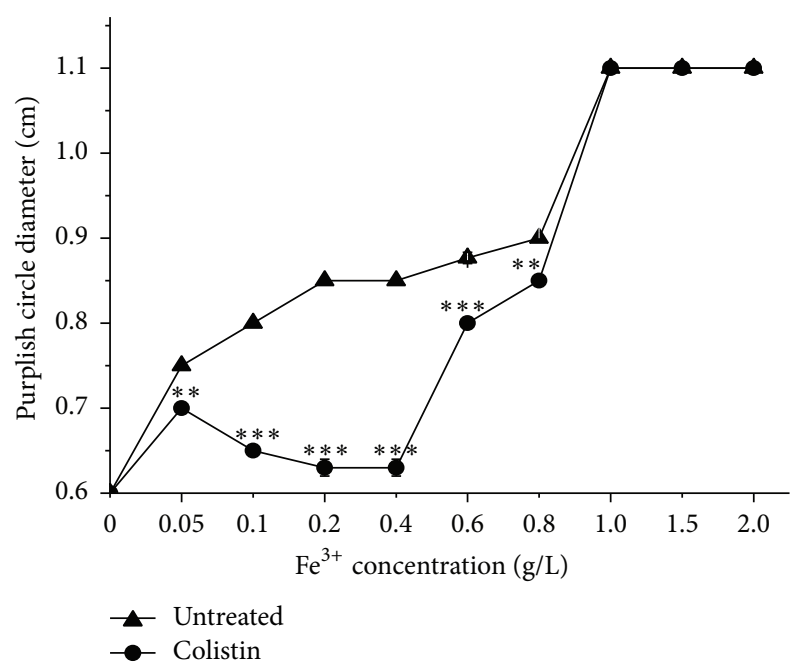

(b)

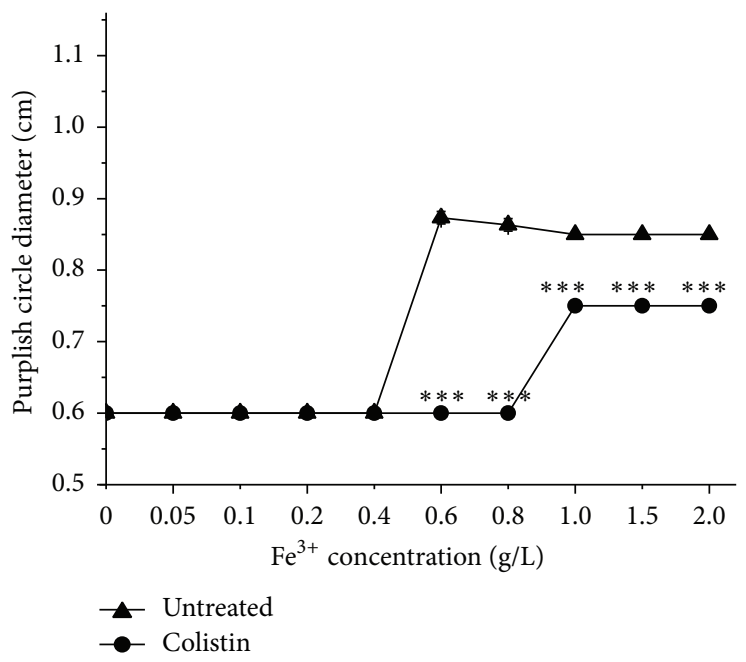

(d)

FIGURE 5: Changes in diameter of purplish red $\mathrm{Fe}^{\mathrm{III}} \mathrm{XO}$ halo formed from supernatant ( $\mathrm{a}$ and $\mathrm{b}$ ) and cell pellet (c and d) of colistin-treated P. polymyxa with various $\mathrm{FeCl}_{3}$. Before detection of purplish red $\mathrm{Fe}^{\mathrm{III}} \mathrm{XO}$ halo formation, there is $\mathrm{H}_{2} \mathrm{O}_{2}$ treatment for (b) and (d), but not for (a) and (c).

\section{Discussion}

With the alarming spread of antibiotic-resistant strains of bacteria, a better understanding of the specific sequence of events leading to cell death by colistin is needed for future drug advancement. As a cyclic lipodecapeptide, colistin carries five free amino groups with five positive charges. It was reported to specifically kill Gram-negative bacteria through membrane lysis by targeting negatively charged LPS and enhancing the permeability of bacterial membrane [4]. In contrast, Gram-positive bacteria are typically believed to be resistant to colistin due to its lack of abundant negatively charged LPS $[23,38]$. It is somewhat surprising that current in vitro work has shown that colistin can also kill Gram-positive bacteria [10, 21, 22], but the bactericidal mechanism is not very clear yet. Recently, it was found that the three major classes of bactericidal antibiotics including $\beta$-lactam, aminoglycoside, and quinolone, regardless of predominantly well-known drug-target interaction, induce the harmful ${ }^{\circ} \mathrm{OH}$ formation in bacteria and cause redoxrelated physiological alteration and toxic metabolic perturbation, ultimately resulting in cell death. Therefore, ROS formation induced by bactericidal antibiotics was proposed as a common mechanism of bacterial death [12-15]. More recently, it was reported that colistin, regardless of common membrane lysis, can also induce ${ }^{\circ} \mathrm{OH}$ production for rapid killing of Gram-negative bacterial cells [11]. In this study, we, for the first time, have shown that colistin can kill $P$. polymyxa, a Gram-positive bacterium, also by inducing ROS. ROS accumulation results in oxidative damage including DNA break, lipid peroxidation, and downregulation of gene expression for Fe-S cluster protein (Figure 2), which is lethal 


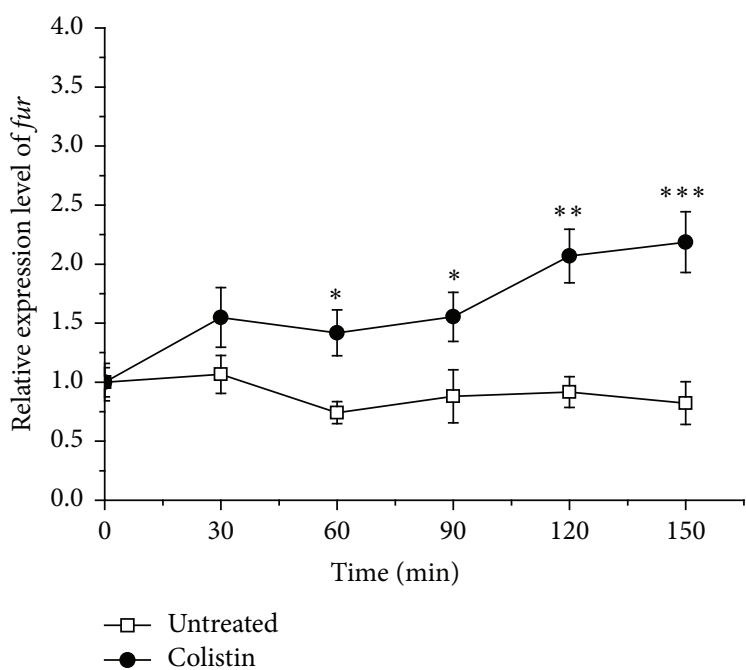

(a)

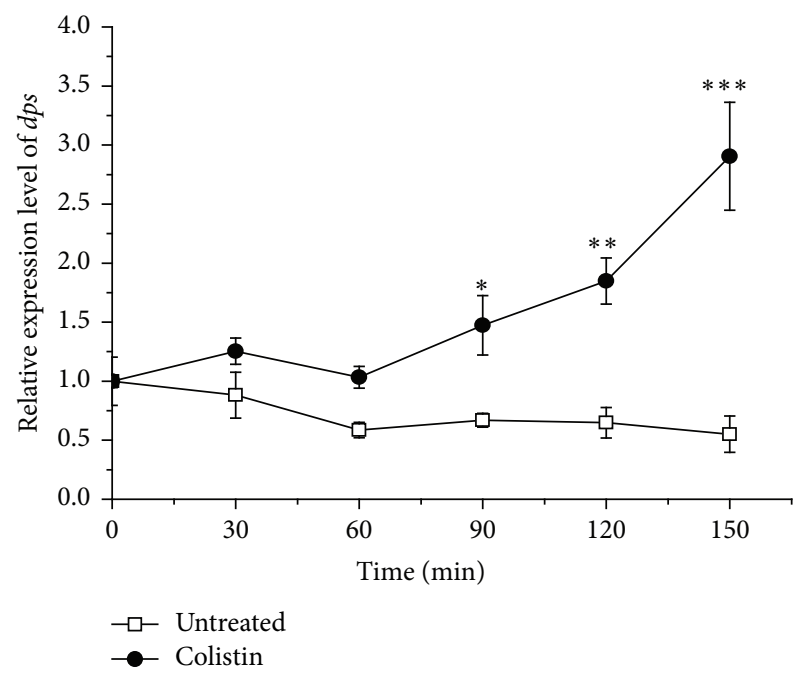

(b)

FiguRE 6: Effect of colistin on relative expression level of fur (a) and $d p s$ (b) encoding for Fur-like protein and DNA-binding protein from starved cells (Dps), respectively, in P. polymyxa.

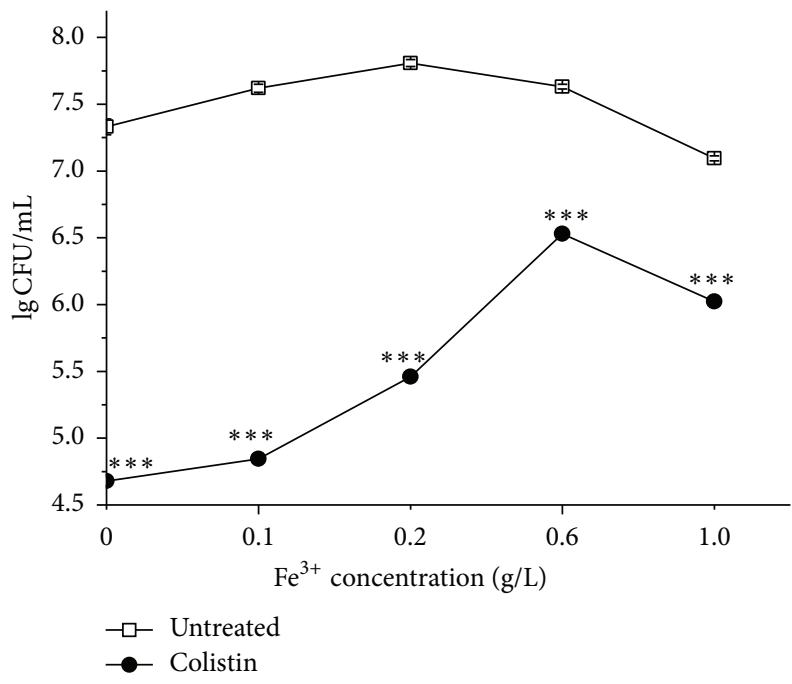

FIGURE 7: Enhancement of survival of colistin-treated P. polymyxa by adding $\mathrm{FeCl}_{3}$.

to cell. The bactericidal activity of colistin against P. polymyxa is both dose- and course-dependent (Figure 1). ROS scavengers including thiourea, cysteine, and glutathione all yield significant increase in P. polymyxa survival following addition of colistin (Figure 3), confirming that colistin-induced ROS is involved in colistin-mediated P. polymyxa cell death. Among these three scavengers, thiourea is the most efficient at mitigating cell death within $2 \mathrm{~h}$ following colistin treatment, which is reflected by the most capacity of thiourea to increase $\mathrm{LgCFU} / \mathrm{mL}$ close to the colistin-absent one. Since thiourea is generally believed to specifically target ${ }^{\circ} \mathrm{OH}$ [12], these results indicate that colistin-induced ${ }^{\circ} \mathrm{OH}$ formation via the Fenton reaction appears to be the most significant contributor to Gram-positive bacterial cell death among the formed ROS.

Our understanding of the bacterial responses that occur as a consequence of colistin treatment remains incomplete. In this study, we found that colistin treatment could increase relative expression of fur encoding for $\mathrm{Fe}^{3+}$ import regulator Fur (Figure 6(a)), which is in line with the stimulation of $\mathrm{Fe}^{3+}$ assimilation (Figure 5). Fur itself is a mononuclear iron protein and tends to lose activity under oxidative stress, which could potentially lead to derepression of iron acquisition system and stimulation of iron import [37]. It is important to note that there is no detectable intracellular $\mathrm{Fe}^{3+}$. Therefore, the assimilated $\mathrm{Fe}^{3+}$ could be used to form $\mathrm{Fe}-\mathrm{S}$ cluster for repairing the oxidative damage, thus providing significantly protective effect against colistin killing (Figure 7). On the other hand, the assimilated $\mathrm{Fe}^{3+}$ could convert to $\mathrm{Fe}^{2+}$ for Fenton-mediated ${ }^{\circ} \mathrm{OH}$ formation by colistin. However, both extracellular and intracellular $\mathrm{Fe}^{2+}$ are undetectable when exposed to abundant $\mathrm{Fe}^{3+}$ up to $0.8 \mathrm{~g} / \mathrm{L}$ following addition of colistin (Figure 5), suggesting that not the abundant external iron import but the intracellular oxidative damage of $\mathrm{Fe}$ $S$ clusters as a key source of ferrous iron drives the ${ }^{\circ} \mathrm{OH}$ formation, which is in agreement with the previous study [12]. In addition, colistin treatment also stimulates the relative expression of $d p s$ encoding for $\mathrm{Fe}^{2+}$ sequester (Figure 6(b)), which is controlled by OxyR regulon [39] and probably a key source of $\mathrm{Fe}^{2+}$ shielding from Fenton chemistry for $\cdot \mathrm{OH}$ reduction. Mn-SOD (encoded by $\operatorname{sod} A$ ) is known to be activated by SoxS transcription factor $[16,39]$. As the first responder in protecting $\mathrm{O}_{2}^{-}$-induced damage, the sodA expression was significantly upregulated following colistin exposure (Figure 4(a)). In addition, the relative expression of Fur-regulated $\operatorname{sodB}$ encoding for Fe-SOD fluctuated increased under colistin (Figure 4(b)), which is in accord with the fluctuation decrease of transcript levels of DHAD 


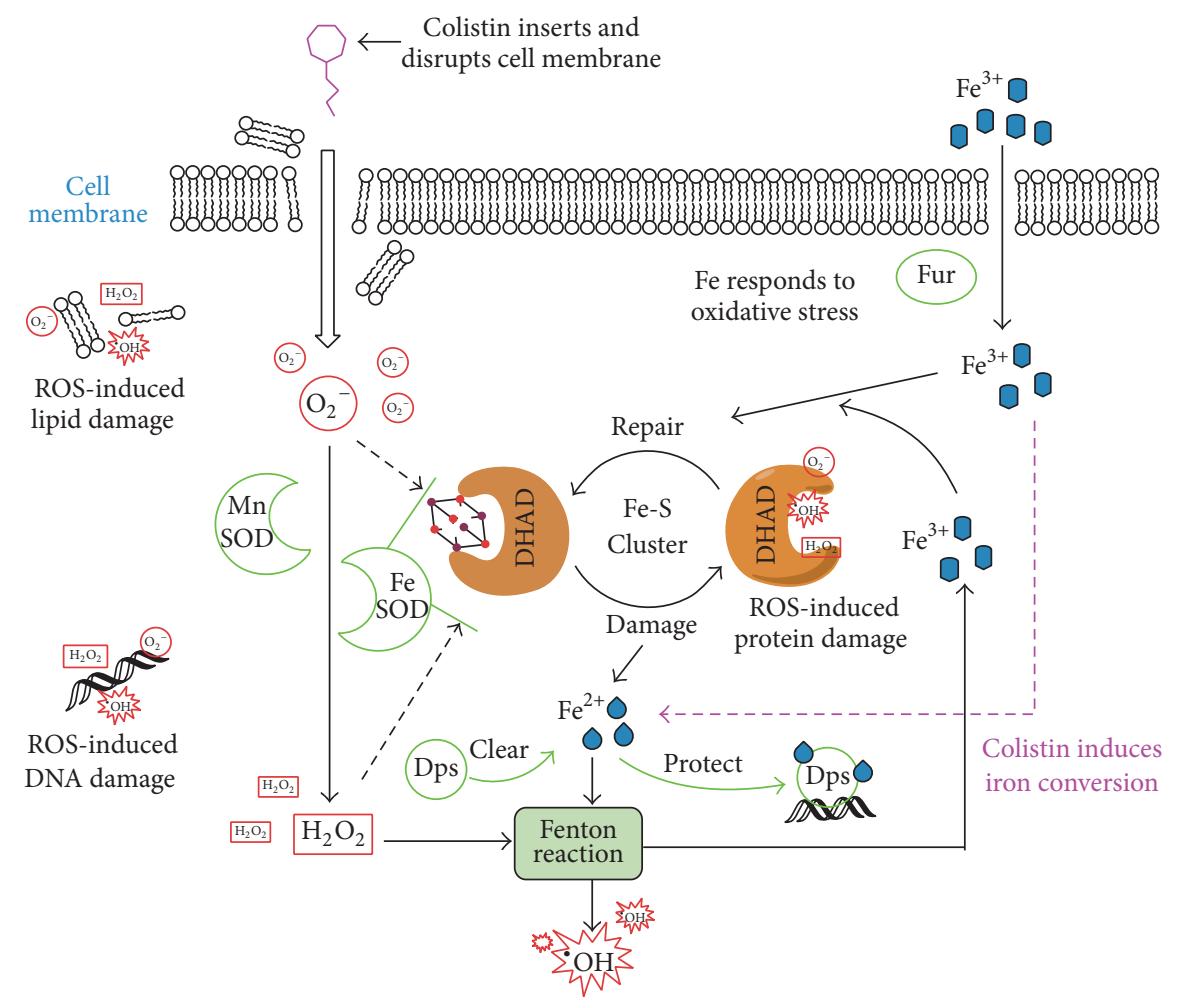

FIGURE 8: Lethal mechanism in Gram-positive bacteria caused by colistin-induced ROS [23].

(Figure 2(d)), thus illustrating that Fe-SOD is important for protecting cytoplasmic enzyme-DHAD from metabolic oxidative damage when exposed to colistin. To survive in colistin exposure, $P$. polymyxa cells have to adjust physiological processes to avoid threatening from oxidative stress [39]. Under control of SoxS regulator, Mn-SOD was activated to remove $\mathrm{O}_{2}{ }^{-}$. OxyR system stimulated Fur synthesis and thereby controlled the $\mathrm{Fe}^{3+}$ import to repair the damaged $\mathrm{Fe}-\mathrm{S}$ clusters. Meanwhile, OxyR-mediated Dps expression alleviated the toxicity of $\mathrm{Fe}^{2+}$ from $\mathrm{Fe}^{3+}$. Subsequently, the activated Fur stimulated the Fe-SOD upregulation to protect DHAD.

In conclusion, our results showed that colistin can possibly induce rapid cell death through induction of ROS formation (Figure 8), a result of the oxidative damage of DNA, lipid, and Fe-S protein (DHAD) due to colistin in $P$. polymyxa $[12,23,38]$. It has been hypothesized that $\mathrm{O}_{2}{ }^{-}$will be induced when colistin enters into and cross cell membrane [12]. Then, $\mathrm{O}_{2}^{-}$will be converted to $\mathrm{H}_{2} \mathrm{O}_{2}$ by $\mathrm{Mn}-\mathrm{SOD}$, and Fe-SOD can protect DHAD from $\mathrm{O}_{2}{ }^{-}$and $\mathrm{H}_{2} \mathrm{O}_{2}$. As a response, $\mathrm{Fe}^{3+}$ will be assimilated into cells with the help of regulator Fur for repairing the inactivated Fe-S cluster. The released $\mathrm{Fe}^{2+}$ from $\mathrm{Fe}-\mathrm{S}$ cluster will participate in Fenton reaction to produce $\mathrm{Fe}^{3+}$ and ${ }^{\bullet} \mathrm{OH}$ (one of ROS). In this $\mathrm{Fe}-\mathrm{S}$ cluster redox cycling, iron conversion is induced by colistin. Besides, Dps can be used to isolate $\mathrm{Fe}^{2+}$ for protection of DNA. Therefore, ROS accumulation and oxidative damage can be induced by colistin in P. polymyxa. Meanwhile, cells will accelerate $\mathrm{Fe}^{3+}$ assimilation and use ROS scavenging system to respond to colistin-induced oxidative stress for survival.

As an essential metal in biology, iron, especially in Fe$S$ cluster, is thought to be one of the earliest iron cofactors, playing an important role in responding oxidative conditions [40]. In this study, we mainly expounded the role of colistin in inducing oxidative stress and iron in repairing oxidative damage in P. polymyxa. P. polymyxa is the producer of colistin. Therefore, understanding of the bactericidal mechanism of colistin against its producer by inducing ROS formation would not only enrich our knowledge of colistin against Gram-positive bacteria but also provide an important guideline based on removal of ROS damage and addition of $\mathrm{Fe}^{3+}$ for optimization of fermentation condition and improvement of colistin output in the future.

\section{Competing Interests}

The authors have declared that no conflict of interests exists.

\section{Authors' Contributions}

Zhiliang Yu and Juanping Qiu contributed equally to this work.

\section{Acknowledgments}

This work was supported by National Natural Science Foundation of China (31670114), Zhejiang Provincial Natural 
Science Foundation of China (LY16C010002), and Regional Demonstration of Marine Economy Innovative Development Project, China (12PYY001SF08), to Zhiliang Yu.

\section{References}

[1] S. Biswas, J.-M. Brunel, J.-C. Dubus, M. Reynaud-Gaubert, and J.-M. Rolain, "Colistin: an update on the antibiotic of the 21st century," Expert Review of Anti-Infective Therapy, vol. 10, no. 8, pp. 917-934, 2012.

[2] A. P. Zavascki, L. Z. Goldani, J. Li, and R. L. Nation, "Polymyxin B for the treatment of multidrug-resistant pathogens: a critical review," Journal of Antimicrobial Chemotherapy, vol. 60, no. 6, pp. 1206-1215, 2007.

[3] A. Z. Bialvaei and H. Samadi Kafil, "Colistin, mechanisms and prevalence of resistance," Current Medical Research and Opinion, vol. 31, no. 4, pp. 707-721, 2015.

[4] T. Velkov, K. D. Roberts, R. L. Nation, P. E. Thompson, and J. Li, "Pharmacology of polymyxins: new insights into an 'old' class of antibiotics," Future Microbiology, vol. 8, no. 6, pp. 711-724, 2013.

[5] R. E. W. Hancock and D. S. Chapple, "Peptide antibiotics," Antimicrobial Agents and Chemotherapy, vol. 43, no. 6, pp. 13171323, 1999.

[6] J.-P. S. Powers and R. E. W. Hancock, "The relationship between peptide structure and antibacterial activity," Peptides, vol. 24, no. 11, pp. 1681-1691, 2003.

[7] P. Pristovšek and J. Kidrič, "The search for molecular determinants of LPS inhibition by proteins and peptides," Current Topics in Medicinal Chemistry, vol. 4, no. 11, pp. 1185-1201, 2004.

[8] Y.-M. Ah, A.-J. Kim, and J.-Y. Lee, "Colistin resistance in Klebsiella pneumoniae," International Journal of Antimicrobial Agents, vol. 44, no. 1, pp. 8-15, 2014.

[9] T. Velkov, P. E. Thompson, R. L. Nation, and J. Li, "Structureactivity relationships of polymyxin antibiotics," Journal of Medicinal Chemistry, vol. 53, no. 5, pp. 1898-1916, 2010.

[10] Z. Yu, Y. Cai, W. Qin, J. Lin, and J. Qiu, "Polymyxin E induces rapid Paenibacillus polymyxa death by damaging cell membrane while $\mathrm{Ca}^{2+}$ can protect cells from damage," PLoS ONE, vol. 10, no. 8, Article ID e0135198, 2015.

[11] T. R. Sampson, X. Liu, M. R. Schroeder, C. S. Kraft, E. M. Burd, and D. S. Weiss, "Rapid killing of Acinetobacter baumannii by polymyxins is mediated by a hydroxyl radical death pathway," Antimicrobial Agents and Chemotherapy, vol. 56, no. 11, pp. 5642-5649, 2012.

[12] M. A. Kohanski, D. J. Dwyer, B. Hayete, C. A. Lawrence, and J. J. Collins, "A common mechanism of cellular death induced by bactericidal antibiotics," Cell, vol. 130, no. 5, pp. 797-810, 2007.

[13] M. A. Lobritz, P. Belenky, C. B. M. Porter et al., "Antibiotic efficacy is linked to bacterial cellular respiration," Proceedings of the National Academy of Sciences of the United States of America, vol. 112, no. 27, pp. 8173-8180, 2015.

[14] D. J. Dwyer, P. A. Belenky, J. H. Yang et al., "Antibiotics induce redox-related physiological alterations as part of their lethality," Proceedings of the National Academy of Sciences of the United States of America, vol. 111, no. 20, pp. E2100-E2109, 2014.

[15] P. Belenky, J. D. Ye, C. B. M. Porter et al., "Bactericidal antibiotics induce toxic metabolic perturbations that lead to cellular damage," Cell Reports, vol. 13, no. 5, pp. 968-980, 2015.

[16] J. Yeom, J. A. Imlay, and W. Park, "Iron homeostasis affects antibiotic-mediated cell death in Pseudomonas species," Journal of Biological Chemistry, vol. 285, no. 29, pp. 22689-22695, 2010.
[17] D. J. Dwyer, M. A. Kohanski, B. Hayete, and J. J. Collins, "Gyrase inhibitors induce an oxidative damage cellular death pathway in Escherichia coli," Molecular Systems Biology, vol. 3, article 91, 2007.

[18] C. Walsh, "Molecular mechanisms that confer antibacterial drug resistance," Nature, vol. 406, no. 6797, pp. 775-781, 2000.

[19] P. Rai, T. D. Cole, D. E. Wemmer, and S. Linn, "Localization of $\mathrm{Fe}^{2+}$ at an RTGR sequence within a DNA duplex explains preferential cleavage by $\mathrm{Fe}^{2+}$ and $\mathrm{H}_{2} \mathrm{O}_{2}$," Journal of Molecular Biology, vol. 312, no. 5, pp. 1089-1101, 2001.

[20] J. A. Imlay, "The molecular mechanisms and physiological consequences of oxidative stress: lessons from a model bacterium," Nature Reviews Microbiology, vol. 11, no. 7, pp. 443-454, 2013.

[21] E. Abachin, C. Poyart, E. Pellegrini et al., "Formation of Dalanyl-lipoteichoic acid is required for adhesion and virulence of Listeria monocytogenes," Molecular Microbiology, vol. 43, no. 1, pp. 1-14, 2002.

[22] Z. Abi Khattar, A. Rejasse, D. Destoumieux-Garzón et al., “The dlt operon of Bacillus cereus is required for resistance to cationic antimicrobial peptides and for virulence in insects," Journal of Bacteriology, vol. 191, no. 22, pp. 7063-7073, 2009.

[23] Z. Yu, W. Qin, J. Lin, S. Fang, and J. Qiu, "Antibacterial mechanisms of polymyxin and bacterial resistance," BioMed Research International, vol. 2015, Article ID 679109, 11 pages, 2015.

[24] H. Ohkawa, N. Ohishi, and K. Yagi, "Assay for lipid peroxides in animal tissues by thiobarbituric acid reaction," Analytical Biochemistry, vol. 95, no. 2, pp. 351-358, 1979.

[25] Z. Yu, C. Guo, and J. Qiu, "Precursor amino acids inhibit polymyxin E biosynthesis in Paenibacillus polymyxa, probably by affecting the expression of polymyxin E biosynthesisassociated genes," BioMed Research International, vol. 2015, Article ID 690830, 11 pages, 2015.

[26] Z. Yu, J. Wang, J. Lin, M. Zhao, and J. Qiu, "Exploring regulation genes involved in the expression of L-amino acid oxidase in Pseudoalteromonase sp. Rf-1," PLoS ONE, vol. 10, no. 3, Article ID e0122741, 2015.

[27] T. D. Schmittgen and K. J. Livak, "Analyzing real-time PCR data by the comparative $C_{\mathrm{T}}$ method," Nature Protocols, vol. 3, no. 6, pp. 1101-1108, 2008.

[28] Z. Yu, J. Wang, N. Zhou, C. Zhao, and J. Qiu, "A highly sensitive method for quantitative determination of L-amino acid oxidase activity based on the visualization of ferric-xylenol orange formation," PLoS ONE, vol. 8, no. 12, Article ID e82483, 2013.

[29] H. H. Jang, K. O. Lee, Y. H. Chi et al., "Two enzymes in one: two yeast peroxiredoxins display oxidative stress-dependent switching from a peroxidase to a molecular chaperone function," Cell, vol. 117, no. 5, pp. 625-635, 2004.

[30] J. A. Imlay, "Pathways of oxidative damage," Annual Review of Microbiology, vol. 57, pp. 395-418, 2003.

[31] J. E. Repine, R. B. Fox, and E. M. Berger, "Hydrogen peroxide kills Staphylococcus aureus by reacting with staphylococcal iron to form hydroxyl radical," Journal of Biological Chemistry, vol. 256, no. 14, pp. 7094-7096, 1981.

[32] D. Touati, "Cloning and mapping of the manganese superoxide dismutase gene $(\operatorname{sod} A)$ of Escherichia coli K-12," Journal of Bacteriology, vol. 155, no. 3, pp. 1078-1087, 1983.

[33] A. Carlioz and D. Touati, "Isolation of superoxide dismutase mutants in Escherichia coli: is superoxide dismutase necessary for aerobic life?" The EMBO journal, vol. 5, no. 3, pp. 623-630, 1986. 
[34] I. R. Tsaneva and B. Weiss, "soxR, a locus governing a superoxide response regulon in Escherichia coli K-12," Journal of Bacteriology, vol. 172, no. 8, pp. 4197-4205, 1990.

[35] C. Geslin, J. Llanos, D. Prieur, and C. Jeanthon, "The manganese and iron superoxide dismutases protect Escherichia coli from heavy metal toxicity," Research in Microbiology, vol. 152, no. 10, pp. 901-905, 2001.

[36] D. Touati, "Iron and oxidative stress in bacteria," Archives of Biochemistry and Biophysics, vol. 373, no. 1, pp. 1-6, 2000.

[37] A. Ilari, P. Ceci, D. Ferrari, G. L. Rossi, and E. Chiancone, "Iron incorporation into Escherichia coli Dps gives rise to a ferritinlike microcrystalline core," Journal of Biological Chemistry, vol. 277, no. 40, pp. 37619-37623, 2002.

[38] J. Li, R. L. Nation, R. W. Milne, J. D. Turnidge, and K. Coulthard, "Evaluation of colistin as an agent against multi-resistant Gramnegative bacteria," International Journal of Antimicrobial Agents, vol. 25, no. 1, pp. 11-25, 2005.

[39] H. Fu, J. Yuan, and H. Gao, "Microbial oxidative stress response: novel insights from environmental facultative anaerobic bacteria," Archives of Biochemistry and Biophysics, vol. 584, article no. 7047, pp. 28-35, 2015.

[40] C. Ayala-Castro, A. Saini, and F. W. Outten, "Fe-S cluster assembly pathways in bacteria," Microbiology and Molecular Biology Reviews, vol. 72, no. 1, pp. 110-125, 2008. 

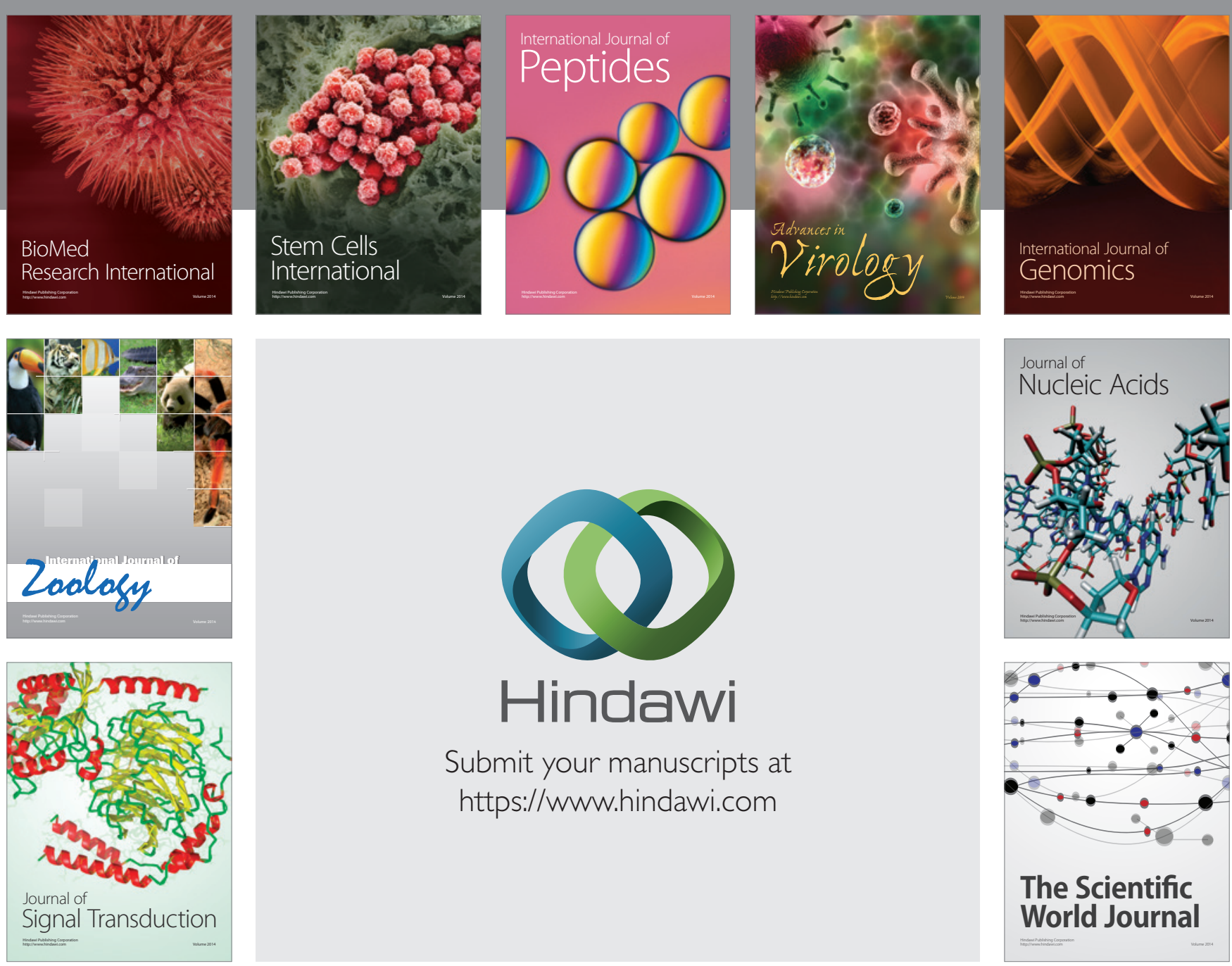

Submit your manuscripts at

https://www.hindawi.com
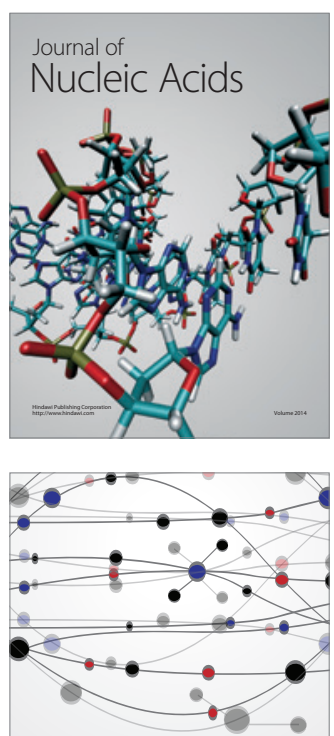

The Scientific World Journal
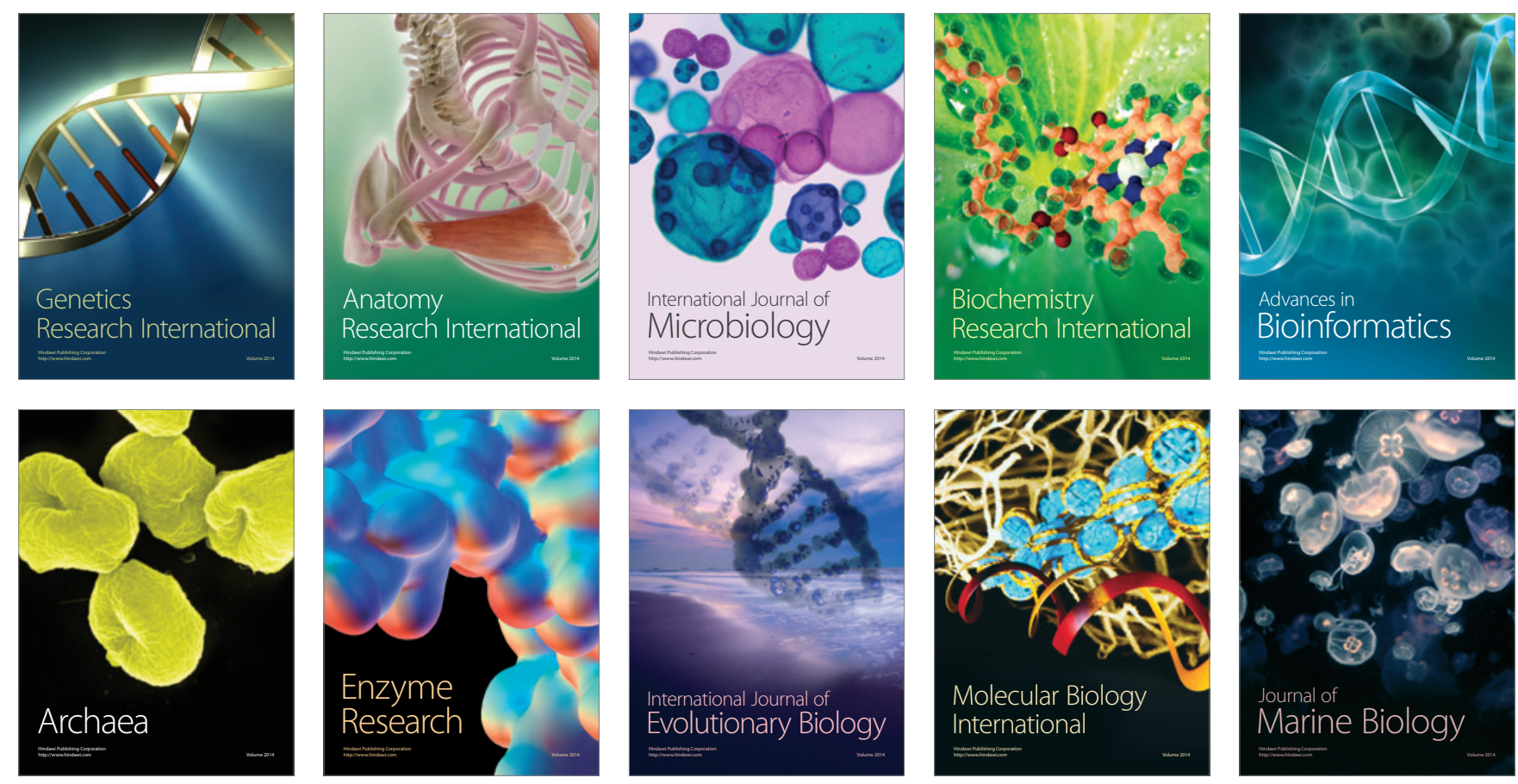